\title{
Effectiveness of Particle Film Technology and Copper Products in the Control of Olive Fruit Fly.
}

Ali, E. A.

Plant Protection Department - Desert Research Center - Cairo - Egypt

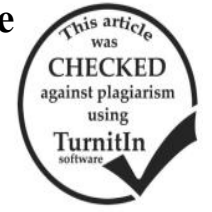

\begin{abstract}
The olive fruit fly, Bactrocera oleae (Gmelin) (Diptera Tephritidae), is the key pest in olive orchards in Egypt. The effectiveness of processed kaolin (Super Nano), Bentonite and copper products ( Kocide 2000 \& Nasr Copper) were tested for controlling olive fruit fly; field trials were conducted during the two years 2013-2014 of Matruoh Governorate, Egypt. The results indicated that Super Nano product in different concentrations suppressed olive fruit fly infestations. The high concentrations of kaolin reduced percentage of olive fruit fly infestations. The best concentration of Super Nano was $5 \%$ but $3 \&$ $4 \%$ concentrations were more economic than 5\%. Data showed that the concentrations 3\%, 4\% and 5\% achieved more than $50 \%$ of reduction percentage of olive fruit fly infestations ranged from $69.3 \%$ to $83.4 \%$ during $2013 \& 2014$. Results proved that the best concentration of bentonite treatment was 5 and $4 \%$ for controlling the olive fruit fly over $3 \%, 2 \%, 1 \%$ and untreated control treatments. The high concentrations of bentonite $(4 \& 5 \%)$ reduced fruit infestation by $(59.4,54.8 \& 72.3 \%)$ and $(46.9,46.4 \&$ $50.7)$, respectively. Bentonite product at $3 \%, 2 \%, \& 1 \%$ reduced the infestation by $(34.3,24.0 \& 16.3 \%)$. Also data cleared that copper hydroxide (Kocide 2000) was more than copper oxychloride in controlling the olive fruit fly causing infestation reduction by $(55.9,59.0 \& 59.9 \%)$ and $(48.0,52.8 \& 58.5 \%)$, respectively. In general Kaolin, Bentonite and copper products are effectively able to limit olive fruit fly infestations to a good level for olive production. These materials can be used also as a new tactic for IPM programs of olive fruit fly in olive fields.
\end{abstract}

Keywords: . Olive fruit fly, kaolin, bentonite, particle film technology, copper products

\section{INTRODUCTION}

Olive fly (Bactrocera oleae Gmelin) in most cultivars develop each year, high population and the infection level reaches up to $99 \%$, meanwhile the losses reached $30 \%$ or more of olive lost has been evaluated owing its attack. Damages are caused due to the quantitative lost such as premature fall of the fruit and the pulp destruction by grub and qualitative lost such as increases of the acidity of the olive and as the consequence the acidity of the olive oil Allmuça et al. (2013). Chemical insecticides have been extensively used in horticultural crop production to control certain pests such as arthropods and mites. Although these chemical insecticides generally belong to different types of chemical compounds, there is still a need for an affective safe alternative demonstrated as not harmful to mammals, birds, fish, beneficial arthropods and environment. Particle film technology has emerged as a new method for controlling arthropod pests and diseases of agricultural crops Glenn et al. (1999). The particle film is based on kaolin and bentonite. Kaolin was a white nonabrasive fine-grained aluminosilicate mineral that has been purified and sized so that it easily disperses in water Harben (1995). The hydrophobic kaolin particle was the first prototype of particle film technology applied to trees as dust to make the plant surfaces water repellent. This material suppressed arthropod pests and diseases by a number of different mechanisms. Fungal and bacterial diseases that require moisture to become infective were suppressed by coating the plant with a hydrophobic particle film barrier that prevented disease inoculum or water from directly contacting the leaf surface. Arthropod infestations were suppressed by particle films for several reasons. Plants coated with a hydrophobic particle film barrier become visually or tactilely unrecognizable as a host. In addition, insect movement, feeding, oviposition, and other activities can also be severely impaired by the attachment of particles to the bodies of the arthropods as they crawled upon the film Puterkalenn et al. (2000). Kaolin is usable in organic farming as a bio stimulant and its use against insects. The powdery film formed by Kaolin on plants may prevent insects from identifying a host crop and consequently insects do not land, feed or lay eggs on the host crop. The coating may also cause insects to deem the fruit or leaves unsuitable Rouini (2008).

The cupric products acting as antibacterial and used in organic farming, which recently introduced good effectiveness in combating $B$. oleae, cause of the symbiosis interruption between the insect and some of the bacteria present on the olives phylloplane, which are vital for the survival of the larva Iannotta et al. (2007b) Belcari (2008). Copper salts through their antibacterial action make fruits less attractive to ovipositing females because of lack of some bacterial compounds on the surface of fruits, furthermore the presence of the particles of those products on fruit surface could be another obstacle for the fruit recognition of the female olive fly Caleca and Rizzo (2007). In organic agriculture the utilization of copper oxychloride as fungicide is allowed, with the recognition of the inspection body or inspection authority Rouini (2008).

Copper could also play an important role to break down the epiphytic bacteria populations. In the recent years, kaolin and copper based products attracted the interest of many olive growers thanks to their efficacy and their relatively simple usage as a physical barrier or repellent against the adults of olive-fruit fly. Benincasa et al. (2008) showed the efficacy of kaolin and copper based products on olive-fruit fly and effects on nutritional and sensory parameters of olive oil. In particular, Randazzo et al. (2011) demonstrated that treatments unaffected the nutritional and sensory 
parameters of the corresponding virgin olive oils satisfying the quality requirements.

The aim of this study to test the effectiveness of two clays (Kaolin (SuperNano) and bentonite) and two copper products (copper hydroxide (Kocide (2000) 53.8 $\%$ DF) \& copper oxychloride (Nasr copper $85 \%$ WP) in controlling of the olive fruit fly in olive orchards.

\section{MATERIALS AND METHODS}

\section{Location and Illustration of the Studied Olive Orchard}

The experiment was conducted in olive grove located in El Matarih, Marsa Matroh in Matrouh Governorate , Egypt that has a typical Mediterranean climate. The orchard was planted with 20 year old of Manzanillo olive c.v. All trees of similar in shape, Vigo unity and conducted to the same agriculture practical. The experiment was conducted during the two years 2013 and 2014. The olive fruit fly population varied from year to year during experimentation. During the experimental months the weather was characterized by moderate to high temperature $\left(23-31{ }^{\circ} \mathrm{C}\right.$ average daily), moderate humidity, slight to moderate winds and lack of rainfall, so the orchard is watered from an artesian well.

\section{2-Experimental Design Sampling Techniques}

The evaluation of the tested compounds carried out during fruit infestation levels from June to November months during the experimental period. Olive fruits were examined for the three presences of the number of infested fruits, pupal and larval tunnels. Total levels of infestation were calculated. Fruit damage was assessed every two weeks comparing with the control up to the harvest. In this study, Four treatments with four replicates were arranged in a completely randomized block design. Each replicate consisted of three trees. Samples of 20 fruits from each tree (replicate) representing different levels and directions of the trees were randomly collected to investigate olive fruit fly attacking fruits. For all treatments, samples of infested fruits were collected immediately before spraying as index of pre - treatment count, and every 15 days after the successive sprays to determine the level of infestation. Samples were collected and examined in the laboratory by using stereoscope microscope. The percentage of reduction in infestation was calculated according to the formula Topps and Wain (1957)

$$
\% \mathrm{R}=\left(\frac{\mathrm{C}-\mathrm{T}}{\mathrm{C}}\right) \quad \mathrm{x} 100
$$

Where :

$\mathrm{C}$ : number of insects recorded in the check samples .

$\mathrm{T}$ : number of insects recorded in treatment samples.

\section{Treatment methods}

In this experiment, two products of particle film technology kaolin $96 \%$ (Super Nano) and Bentonite $100 \%$ (Bentonite product) were tested against olive fruit fly in five concentrations $1,2,3,4$, and $5 \%$ each one respectively. Super Nano and Bentonite were compared with Kocide 2000, containing 53.8\% DF of copper hydroxide and Nasr Copper $85 \%$ WP copper oxychloride, at the recommended dose. The olive trees were sprayed (twelve times) every two weeks with each of the two products of particle film technology (Super Nano and Bentonite) from the first of June to November (till harvesting) against olive fruit fly insect. Spraying was accomplished by a six horses power motor sprayer "Beem" with $600 \mathrm{~L}$ tank, at the rate of $12-16 \mathrm{~L}$. per tree. Copper sprayings were done on July $20^{\text {th }}$, August $20^{\text {th }}$, September $20^{\text {th }}$ and October $20^{\text {th }}$, in 2013 and 2014 . As for copper, the first spraying was applied after the first eggs were laid and favorable. The second spraying was done about one month later, in order to maintain an adequate presence of the matter during the whole experimental period. The insecticide concentrations applied in field experiments were calculated according to the recommendations of Egyptian Ministry of Agriculture with 180 g / 100 L for Kocide 2000 and 200 g /100 L for Copper oxychloride. Cheek trees were left without treatment.

\section{The statistical analysis}

The experiments were analyzed by ANOVA according to completely randomized design. The proper 'F 'test and Duncan's multiple range test were followed. N.S. indicates that differences between treatments were not significant, whereas $*$ and $* *$ indicate that differences are significant and highly significant, respectively. Differences between the averages followed by the same letters are insignificant.

\section{RESULTS AND DISCUSION}

\section{Particle film technology \\ Kaolin Treatments}

The obtained data in Tables ( 1 \& 2) indicated that infestation was significantly lower in the treated olives than untreated ones. The results of the first season (table1) cleared that after the kaolin spray (Super Nano) cumulative olive fruit fly infestation, larvae and pupa average number through the season in treated trees at concentrations $1 \%, 2 \%, 3 \%, 4 \%$ and $5 \%$ were $(51.5$, $9.5 \& 15.0),(40.7,7.7 \& 11.0),(26.4,4.6 \& 7.0),(19.8$, $4.1 \& 4.8)$ and $(14.2,2.8 \& 2.7)$, respectively as compared with $(86.0,21.8 \& 21.2)$ in the untreated trees. Super Nano treatment reduced infestation, larvae and pupa by $(40.4,56.4 \& 29.2 \%),(52.7,64.7 \& 48.1$ $\%$ ), (69.3, $78.9 \& 67.0 \%),(77.0,81.2 \& 77.4)$ and (83.4, 87.2 \& 87.3) for different concentrations, respectively.

The results obtained in the second season, in Table 2 appeared a similar trend to the first season. Treating olive trees as kaolin treatments with concentrations $1 \%, 2 \%, 3 \%, 4 \%$ and $5 \%$ reduced infestation, larvae and pupa by $(41.0,58.5 \& 37.9 \%)$, $(49.9,66.5 \& 50.2 \%),(69.8,78.6 \& 67.8 \%),(77.2,81.5$ $\& 78.9 \%)$ and $(83.4,86.7 \& 84.6 \%)$, respectively. Their cumulative average number of fruit infestation were (54.0, $10.3 \& 14.1),(41.7,8.3 \& 11.3),(27.7,5.3 \& 7.3)$, $(20.9,4.6 \& 4.8) \&(15.2,3.3 \& 3.5)$ respectively, as compared with $(91.6,24.8 \& 22.7)$ in the untreated control trees.

These results indicated that kaolin (Super Nano) product in different concentrations suppressed olive fruit fly infestations. When the concentrations of kaolin 
was highly, the reduction percentage of infestations was highly too for control olive fruit fly. The best concentration of Super Nano was $5 \%$ but $3 \& 4 \%$ concentrations were more economic than 5\%. The data showed that the concentrations $3 \%, 4 \%$ and $5 \%$ achieved more than $60 \%$ reduction of olive fruit fly infestations on olive trees that ranged from $69.3 \%$ to $83.4 \%$ reduction of infestation of olive fruit fly in the two seasons 2013 \& 2014. These results was agreed with Mozhdehi and Kayhanian (2014) They reported that concentration of $5 \%$ kaolin has been recommended for spraying on olive trees. The previous results, mentioned that application of kaolin powder was very useful to control of olive fruit fly and will be one of the methods in IPM. It is allowed that kaolin may be alternative to broad spectrum insecticides against olive fruit fly. In addition, these results parallel with those of Daniel et al. (2005) who found that processed kaolin may be an alternative to broad-spectrum insecticides used against European pear sucker, Cacopsylla pyri (L.), in organic and conventional pear production.

In conclusion, fruit infestation levels were significantly reduced due to kaolin-treated trees compared with untreated trees. The promising results of these experiments points to the feasibility of using particle film technology composed of a non-toxic material, to avoid olive fly damage as an alternative to the applications of insecticide in organic orchards. Finally, kaolin treatment unaffected the nutritional and sensory quality parameters of the corresponding virgin olive oils obtained by a laboratory scale olive mill, thus satisfying the present quality requirements Perri et al. (2005).

Table (1):Cumulative infestation of olive fruit fly (Bactrocera oleae) in olive groves treated with different concentrations of kaolin as particle film technology, throughout season 2013.

\begin{tabular}{|c|c|c|c|c|c|c|c|c|c|c|}
\hline \multirow{3}{*}{$\begin{array}{l}\text { Treatments } \\
\text { Conc. } \\
\text { (W/V) }\end{array}$} & \multicolumn{10}{|c|}{ Infested Fruits * } \\
\hline & \multicolumn{2}{|c|}{$\begin{array}{c}\text { Total } \\
\text { Number }\end{array}$} & \multicolumn{2}{|c|}{ Larvae } & \multicolumn{2}{|c|}{$\begin{array}{l}\text { Empty } \\
\text { Larvae }\end{array}$} & \multicolumn{2}{|c|}{ Pupa } & \multicolumn{2}{|c|}{$\begin{array}{l}\text { Empty } \\
\text { Pupa }\end{array}$} \\
\hline & Mean & $\% \mathrm{R}$ & Mean & $\% \mathrm{R}$ & Mean & $\% R$ & Mean & $\% R$ & Mean & $\% \mathrm{R}$ \\
\hline $1 \%$ & 51.5 & 40.1 & 9.5 & 56.4 & 13.0 & 43.5 & 15.0 & 29.2 & 14.0 & 30.0 \\
\hline $2 \%$ & 40.7 & 52.7 & 7.7 & 64.7 & 11.0 & 52.2 & 11.0 & 48.1 & 11.0 & 45.0 \\
\hline $3 \%$ & 26.4 & 69.3 & 4.6 & 78.9 & 7.2 & 68.7 & 7.0 & 67.0 & 7.6 & 62.0 \\
\hline $4 \%$ & 19.8 & 77.0 & 4.1 & 81.2 & 5.4 & 76.5 & 4.8 & 77.4 & 5.5 & 72.5 \\
\hline $5 \%$ & 14.2 & 83.4 & 2.8 & 87.2 & 3.6 & 84.3 & 2.7 & 87.3 & 5.1 & 74.5 \\
\hline Control & 86.0 & & 21.8 & & 23.0 & & 21.2 & & 20.0 & \\
\hline LSD & 1.2 & & 0.7 & & 0.3 & & 0.6 & & 0. & \\
\hline
\end{tabular}

\% R = Reduction Percentage

* Cumulative number of infested fruits all over the growing season (12 dating samples)

\section{Bentonite Treatments}

As shown in Table (3) the obtained results in first season (2013) indicated that infestation was significantly lower in the treated olives than untreated ones. The data proved the superiority of the concentration of bentonite treatment was $5 \%$ and 4 in controlling the olive fruit fly However, the lower effect achieved from $3 \%, 2 \%, 1 \%$ and untreated control treatments. The cumulative average number of total infested fruits, larvae and pupa as affected by $5 \%, 4 \%$, $3 \%, 2 \% \& 1 \%$ were $(42.7,10.9 \& 7.5),(49.0,13.0 \&$ $11.3),(56.5,15.6 \& 12.3),(65.4,14.6 \& 16.6)$ and
(72.0, $16.8 \&$ \& 17.2), respectively as compared with $(86.0,21.8 \& 21.2)$ in the untreated control treatment, representing $(50.3,50.5 \& 64.6 \%),(43.0,40.4 \& 46.7$ $\%),(34.3,28.4 \&, 42.0 \&),(24.0,33.0 \& 21.7 \%)$ and $(16.3,22.9 \& 18.9 \%)$ reduction of infestations, respectively. The similar results was found between the above results in the first season and those obtained from the second season 2014. Table 4 revealed that bentonite $5 \%$ was the most effective concentration followed by bentonite $4 \%$. They reduced fruit infestation by $(59.4$, $54.8 \& 72.3 \%)$ and $(46.9,46.4 \& 50.7)$, respectively. Bentonite product in concentrations $3 \%, 2 \%, \& 1 \%$ reduced the infestation by less than half.

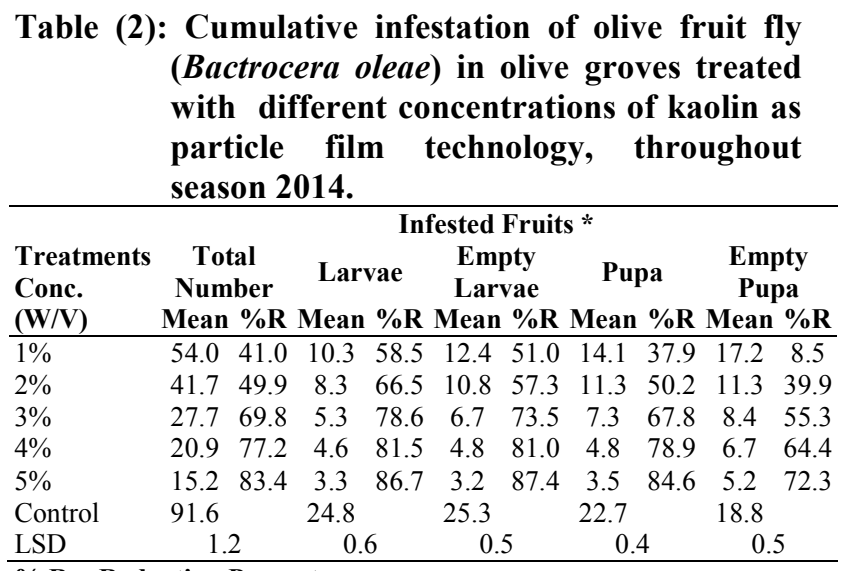

$\% \mathbf{R}=$ Reduction Percentage

* Cumulative number of infested fruits all over the growing season (12 dating samples)

The previous results, mentioned that bentonite treatments gave moderate control against olive fruit fly while there were a little pronounced effects of $5 \%$ and $4 \%$ concentrations. This results was in agreement with obtained by Muccilli (2010) who mentioned that kaolin, bentonite and cupper product treatments gave successful control against olive fruit fly. The applications of different combinations of clays product Surround WP, compared to copper hydroxide, oxichloride and bentonite products have shown good results and new opportunities in organic farm for table olive production.

The results obtained in the two studied years indicated that particle film technology (kaolin \& bentonite) has great potential for the control of $B$. oleae population. It is sprayed onto canopy as a liquid suspension while water evaporates leaving kaolin as a white porous protective powdery film on the leaves and fruits surface. The kaolin \& bentonite-based particle film caused a reduction of adult population. Although it is not directly toxic to insects However, its insecticidal properties are repellent nature, antiovipositional qualities or due to its highly reflective white coating. Moreover, as a consequence of the repulsion of gravid females due to abovementioned behavioral reasons and the tactile unsuitable texture of particle film treated olives, data concerning active infestation percentages in the theses treated with kaolin, bentonite and copper products registered a significant reduction. However, the environmental impact eventually associated with 
kaolin application should be evaluated Iannotta et al. (2007a).

Table(3):Cumulative infestation by olive fruit fly (Bactrocera oleae) in olive groves treated with different concentrations of bentonite as particle film technology throughout season 2013.

\begin{tabular}{|c|c|c|c|c|c|c|c|c|c|c|}
\hline \multirow{3}{*}{$\begin{array}{l}\text { Treatments } \\
\text { Conc. } \\
\text { (W/V) }\end{array}$} & \multicolumn{10}{|c|}{ Infested Fruits * } \\
\hline & \multicolumn{2}{|c|}{$\begin{array}{c}\text { Total } \\
\text { Number }\end{array}$} & \multicolumn{2}{|c|}{ Larvae } & \multicolumn{2}{|c|}{$\begin{array}{l}\text { Empty } \\
\text { Larvae }\end{array}$} & \multicolumn{2}{|c|}{ Pupa } & \multicolumn{2}{|c|}{$\begin{array}{c}\text { Empty } \\
\text { Pupa }\end{array}$} \\
\hline & Mean & $\% R$ & Mean & $\% R$ & Mean & $\% R$ & Mean & $\% R$ & Mean & $\% R$ \\
\hline $1 \%$ & 72.0 & 16.3 & 16.8 & 22.9 & 18.2 & 20.9 & 17.2 & 18.9 & 19.8 & 1.0 \\
\hline $2 \%$ & 65.4 & 24.0 & 14.6 & 33.0 & 14.8 & 35.7 & 16.6 & 21.7 & 19.4 & 3.0 \\
\hline $3 \%$ & 56.5 & 34.3 & 15.6 & 28.4 & 12.3 & 45.5 & 12.3 & 42.0 & 16.3 & 18.5 \\
\hline $4 \%$ & 49.0 & 43.0 & 13.0 & 40.4 & 10.3 & 55.2 & 11.3 & 46.7 & 14.4 & 28.0 \\
\hline $5 \%$ & 42.7 & 50.3 & 10.9 & 50.0 & 9.3 & 59.6 & 7.5 & 64.6 & 15.0 & 25.0 \\
\hline Control & 86.0 & & 21.8 & & 23.0 & & 21.2 & & 20.0 & \\
\hline LSD & 1 & .5 & 0.8 & & 0. & & 0 . & & 0. & \\
\hline
\end{tabular}

\% R = Reduction Percentage

* Cumulative number of infested fruits all over the growing season (12 dating samples)

Table(4):Cumulative infestation by olive fruit fly (Bactrocera oleae) in olive groves treated with different concentrations of bentonite as particle film technology, throughout season 2014.

\begin{tabular}{|c|c|c|c|c|c|c|c|c|c|c|}
\hline \multirow{3}{*}{$\begin{array}{l}\text { Treatments } \\
\text { Conc. }(W / V)\end{array}$} & \multicolumn{10}{|c|}{ Infested Fruits * } \\
\hline & \multicolumn{2}{|c|}{$\begin{array}{c}\text { Total } \\
\text { Number }\end{array}$} & \multirow{2}{*}{\multicolumn{2}{|c|}{$\begin{array}{c}\text { Larvae } \\
\text { Mean \%R }\end{array}$}} & \multicolumn{2}{|c|}{$\begin{array}{l}\text { Empty } \\
\text { Larvae }\end{array}$} & \multicolumn{2}{|c|}{ Pupa } & \multicolumn{2}{|c|}{ Empty Pupa } \\
\hline & Mean & $\% \mathrm{R}$ & & & Mean & $\% \mathrm{R}$ & Mean & $\% R$ & Mean & $\% R$ \\
\hline $1 \%$ & 71.6 & 21.8 & 21.9 & 11.7 & 15.4 & 39.1 & 13.0 & 42.7 & 721.3 & -13.3 \\
\hline $2 \%$ & 65.1 & 28.9 & 17.9 & 27.8 & 13.0 & 48.6 & 14.3 & 37.0 & 19.9 & -5.9 \\
\hline $3 \%$ & 57.0 & 37.8 & 15.0 & 39.5 & 11.2 & 55.1 & 13.2 & 41.9 & 17.6 & 6.4 \\
\hline $4 \%$ & 48.6 & 46.9 & 13.3 & 46.4 & 10.9 & 56.9 & 11.2 & 50.7 & 713.2 & 29.8 \\
\hline $5 \%$ & 37.2 & 59.4 & 11.2 & 54.8 & 10.3 & 59.3 & 6.3 & 72.3 & 9.4 & 50.0 \\
\hline Control & 91.6 & & 24.8 & & 25.3 & & 22.7 & & 18.8 & \\
\hline LSD & 1. & & 0. & 6 & 0. & .4 & 0. & & 0 . & .9 \\
\hline
\end{tabular}

$\% \mathbf{R}=$ Reduction Percentage

* Cumulative number of infested fruits all over the growing season (12 dating samples)

\section{Copper products}

As shown in Table (5) the results obtained in the first season (2013) indicated that infestation was significantly lower in the treated olives than untreated ones. The data proved the superiority of Kocide in controlling the olive fruit fly over Nasr Copper product. The cumulative average number of total infested fruits, larvae and pupa as affected by kocide 2000 and Nasr Copper were $(37.9,8.8 \& 8.5)$ and $(44.0,10.3 \& 8.8)$, respectively as compared with $(86.0,21.8 \& 21.2)$ fruits in the untreated control treatment, representing (55.9, $59.6 \& 59.9 \%)$ and $(48.8,52.8 \& 58.5 \&)$ reduction of infestations, respectively. An agreement was found between the above results in the first season and those obtained from the second season 2014 (Table 6) which revealed that Kocide 2000 was more effective than Nasr Copper. They reduced fruit infestation by $(48.9,56.9 \&$ 55.1) and (39.2, $50.0 \& 43.2$, respectively.

These results indicated that Copper hydroxide and copper oxychloride suppressed olive fruit fly infestations on olive trees. These results agreed with Calec and Rizzo (2006) who said that copper hydroxide and oxychloride, kaoline and bentonite are effectively able to limit $B$. oleae infestations to a good level for olive oil production, moreover considering these products particularly for controlling the olive fruit fly also in organic farms give a new opportunity for controlling the olive fruit fly also in organic farms for table olives productions. There were interaction between both larvae of olive fruit fly and their associated bacteria, and fruit chemical defense, hypothesizing that bacterial contribution to larval development is contingent on the phenology of fruit defensive chemistry. We demonstrate that larvae require their natural complement of bacteria (Candidatus Erwinia dacicola: Enterobacteriaceae) in order to develop in unripe olives. Conversely, when feeding on ripe fruit, larval development proceeds independently of these bacteria. That were suggested that the unique symbiosis in olive flies, compared with other frugivorous tephritids, is understood by considering the relationship between the fly, bacteria and fruit chemistry Ben-Yosef et al. (2015). Copper products were used to suppress bacteria that effects on the potential of olive fruit fly larva. Cupper products applications can be used also as a new tactic for IPM of olive fruit fly in olive fields. The use of antibacterial substances, as copper products, showed a good efficacy on both adult and preimago population. The copper application seemed to be particularly efficacious suggesting that acts by interrupting the symbiosis among the olive fly female and larvae and some bacteria present on olive phylloplane It has been demonstrated that one of the most important food sources for some many oriental species of the genus Bactrocera oleae are bacteria from the phyloplane of oriental fruits. Several research studies have shown the existence of a relationship between epiphytic bacteria and the olive fruit fly. Bacteria are important as a source of food for adults and as sympionts for young larvae; in fact, protein hydrolysis only occurs in young larva when bacteria are present in the blind sac of the gut. Certain chemical compounds such copper could play an important role as symbiosis inhibitors Rosi et al. (2005). These compounds proved to have good level of effectiveness in reducing infestation in the treated olives.

Table (5): Cumulative infestation by olive fruit fly (Bactrocera oleae)in olive groves treated with copper products throughout season 2013.

\begin{tabular}{|c|c|c|c|c|c|c|c|c|c|}
\hline \multirow[b]{2}{*}{ Treatments } & \multicolumn{9}{|c|}{ Infested Fruits * } \\
\hline & $\begin{array}{r}\text { Tot } \\
\text { Num } \\
\text { Mean }\end{array}$ & $\begin{array}{l}\text { tal } \\
\text { ber } \\
\% R\end{array}$ & $\begin{array}{r}\text { Lar } \\
\text { Mean }\end{array}$ & $\begin{array}{l}\text { vae } \\
\% R\end{array}$ & $\begin{array}{r}\text { Emp } \\
\text { Larv } \\
\text { Mean }\end{array}$ & $\begin{array}{l}\text { pty } \\
\text { vae } \\
\% R\end{array}$ & $\begin{array}{r}\text { Pup } \\
\text { Mean }\end{array}$ & $\begin{array}{l}\text { pa } \\
\% R\end{array}$ & $\begin{array}{c}\text { Empty } \\
\text { Pupa } \\
\text { Mean \%R }\end{array}$ \\
\hline $\begin{array}{l}\text { Copper } \\
\text { hydroxide } \\
(53.8 \%)\end{array}$ & 37.9 & 55.9 & 8.8 & 59.6 & 9.4 & 59.1 & 8.5 & 59.9 & 11.244 .0 \\
\hline $\begin{array}{l}\text { Oxychloride } \\
\text { copper } \\
(85 \%)\end{array}$ & 44.0 & 48.8 & 10.3 & 52.8 & 10.6 & 53.9 & 8.8 & 58.5 & $14.3 \quad 28.5$ \\
\hline Control & 86.0 & & 21.8 & & 23.0 & & 21.2 & & 20.0 \\
\hline LSD & $1 .($ & & 0. & & 0.4 & & 0.6 & 6 & 0.4 \\
\hline
\end{tabular}

$\% \mathbf{R}=$ Reduction Percentage

* Cumulative number of infested fruits all over the growing season (12 dating samples) 
Table (6): Cumulative infestation by olive fruit fly (Bactrocera oleae) in olive groves treated with copper products throughout season 2014.

\begin{tabular}{|c|c|c|c|c|c|}
\hline \multirow[b]{3}{*}{ Treatments } & \multicolumn{5}{|c|}{ Infested Fruits * } \\
\hline & $\begin{array}{c}\text { Total } \\
\text { Number }\end{array}$ & Larvae & $\begin{array}{l}\text { Empty } \\
\text { Larvae }\end{array}$ & Pupa & $\begin{array}{c}\text { Empty } \\
\text { Pupa }\end{array}$ \\
\hline & Mean \%R & Mean $\% \mathbf{R}$ & Mean $\% \mathrm{R}$ & Mean $\% \mathbf{R}$ & Mean $\% R$ \\
\hline $\begin{array}{l}\text { Copper } \\
\text { hydroxide } \\
(53.8 \%)\end{array}$ & 46.848 .9 & 10.756 .9 & 12.749 .8 & 10.255 .1 & 13.229 .8 \\
\hline $\begin{array}{l}\text { Oxychloride } \\
\text { copper } \\
(85 \%)\end{array}$ & 55.739 .2 & 12.450 .0 & 14.443 .1 & 12.943 .2 & 16.014 .9 \\
\hline Control & 91.6 & 24.8 & 25.3 & 22.7 & 18.8 \\
\hline LSD & 1.2 & 0.5 & 0.8 & 0.5 & 0.6 \\
\hline
\end{tabular}

$\% \mathbf{R}=$ Reduction Percentage

* Cumulative number of infested fruits all over the growing season (12 dating samples)

\section{CONCLUSIONS}

It is no doubt that the kaolin clay has some advantages unlike copper products. It has no environmental toxicity, due to white coating from kaolin sprays the need of further treatments is easily detectable by the growers watching the fruits in the field. Further copper hydroxide and oxychloride, kaolin and bentonite are effectively able to limit $B$. oleae infestations to a good level. Moreover considering these products particularly for controlling the olive fruit fly also in organic farms give a new opportunity for controlling the olive fruit fly also in organic farms for table olives productions.

\section{REFRENCES}

Allmuça, F. ; D. Stefan and R. Uka (2013). Olive Fly (Bactrocera Oleae Gmelin) Management with new allowed formulation, satisfying the olive oil quality requirement. International Refereed Journal of Engineering and Science 2 (5) ; $9-13$.

Belcari, A. (2008). Uso di prodotti a base di rame nella lotta a Bactrocera oleae, in Atti del Convegno nazionale sulla ricerca scientifica per l'agricoltura biologica, Guido Editore, Rende (CS) ; 40-48.

Benincasa, C.; B. C. Bati; N. Iannotta ; M. Pellegrino ; G. Pennino; B. Rizzuti and E. Romano (2008). Efficacy of kaolin and copper Based products on olive-fruit fly (B. aloea Gmelin) and effects on nutritional and sensory parameters of olive oils. Riv. Sci. Alim. $4: 21-31$.

Ben-Yosef, M.; Z. Pasternak; E. Jurkevitch and B. Yuval (2015). Symbiotic bacteria enable olive fly larvae to overcome host defences. Rsos.royalsocietypublishing.org

Caleca, V. and R. Rizzo (2006). Effectiveness of clays and copper products in the control of Bactrocera oleae (Gmeline). Olivebiootaq November $5^{\text {th }}-$ $10^{\text {th }}$. Mazara del vallo, , Marsalla Italy 19-25.

Caleca, V. and R. Rizzo (2007). Tests on the effects of kaolin and copper hydroxide in the control of Bactrocera oleae (Gmeline). 2 nd European meeting of the IOBC/WPRS study Group "Integrated Protection of olive crops." 4-7.
Daniel, C. ; W. Pfammatter ; P. Kehrli and E. Wyss (2005). Processed kaolin as an alternative insecticide against the European pear sucker, Cacopsylla pyri (L.) Journal of Applied Entomology $\cdot 129$ (7) ; 363-367

Glenn, D. M.; G. J. Puterka; T. Vanderzwet; R. E. Byers and C. Feldhake (1999). Hydrophobic particle films: a new paradigm for suppression of arthropod pests and plant diseases. J. Econ. Entomol. 92 (4) : 759-771.

Harben, P. W. (1995). The industrial minerals handbook 11: a guide to markets, specifications and prices. Arby Industrial Minerals Division Metal Bull. PLc, London.

Iannotta, N. ; T. Belfiore ; M. E. Noce ; S. Scalercio and V. Vizzarri (2007a). Bactrocera oleae (Gmelin) control in organic olive farming. Ecoliva 2007- VI Jornadas Internacionales de Olivar Ecologico, Puente de Génave (Jaén), España, Marsh 22-25 http://www .ecoliva. info/index.php?option $=$ com_content\&task $=$ blogc ategory\&id $=17 \&$ Itemid $=38$.

Iannotta, N.; T. Belfiore; M. E. Noce; S. Scalercio and V. Vizzarri (2007b) Bactrocera pleae (GMELIN) control in organic farming. Ecoliva, VI Jornadas Internacionales de Olivar Ecologico, Puente de Génave (Jaén), Espåna, 22-25 marzo

Mozhdehi1, M. R. A. and A. A. Kayhanian (2014). Application of deterrent compound for control of olive fruit flies Bactrocera oleae(Gmelin) (Diptera Tephritidae). Romanian Journal of Plant Protection Vol. VII ; 24-30

Muccilli, S. (2010). Isolation and characterizations of yeasts isolated from naturally fermented olive brine with bioprotective functions. Phd thesis. Universita Deglistudi Di Catania, PP ;1-182

Perri, E.; N. Iannotta; I. Muzzalupo; A. Russo; M. A. Caravita; M. Pellegrino; A. Parise and P. Tucci (2005). Kaolin protects olive fruits from Bactrocera oleae (Gmelin) infestations unaffecting olive oil quality. $2^{\text {nd }}$ European Meeting of the IOBS/WPRS Study group Integrated Protection of olive crops, Florence, 26-28 October; To be published in IOBC/WPRS Bulletin.

Puterkalenn, D. M.; D. G. Sekutowski; T. R. Unruh and S. K. Jones (2000). Progress toward liquid Environ. Entomol. 29 (2) ; 329-339.

Randazzo, C. I.; G. Fava; F. Tomas Elli ; F. V. Romeo ; G. Pennino; E. Vitello and C. Caggia (2011). Effect of kaolin and copper based products and of starter cultures on green table olive fermentation. Food Microbiology 28910 - 919.

Rosi, M.C.; M. Librandi; P. Sacchetti and A. Belcari (2005). Effects of copper sprays on the olive fly in organic olive orchards. Abstract Book, $2^{\text {nd }}$ European Meeting of the IOBC/WPRS Study Group "Integrated Protection of Olive Crops", Florence, 78 (10) ; 26-28. 
Ali, E. A.

Rouini, I. (2008). Olive fly management with allowed formulations in organic agriculture. Thesis requise pour submitted Master of Science in "Mediterranean Organic Agriculture"
Topps, J. H. and R. L. Wain (1957). Investigation on Fungicides III the fungi toxicity of 3 and $5-$ alkyl- Salicyl - anilides and P - Chloroanilines. Ann. Appl. Biol., 45 (3) ; 506 - 511. (C. F. El Shazlyal Zein (1983)).

\section{فاعلية تكنيك الطبقة الرقيقة من الجزيئات ومنتجات النحاس فى مكافحة ذبابة ثمار الزيتون

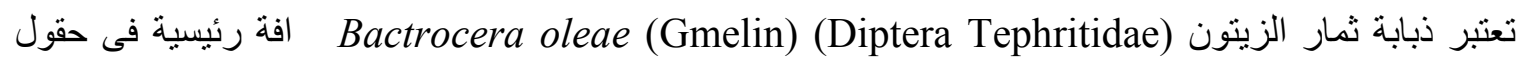

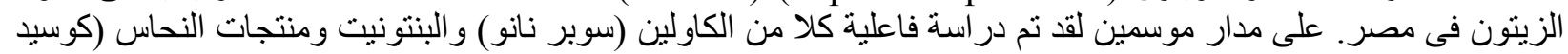

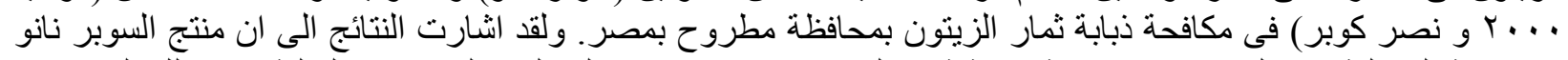

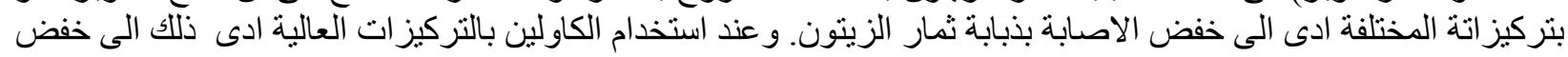

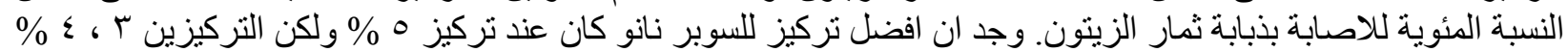

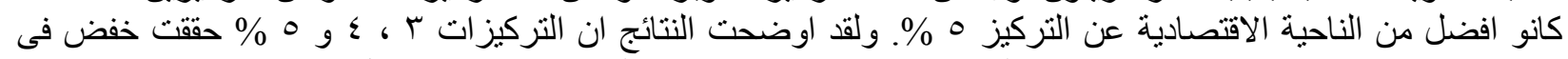

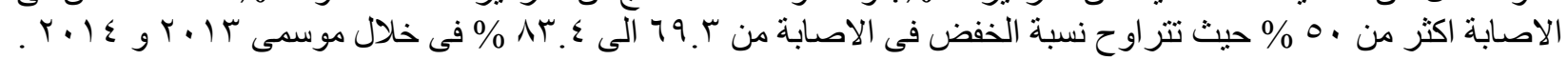

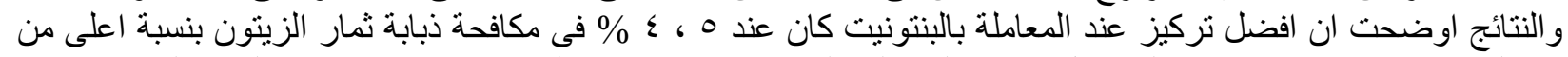

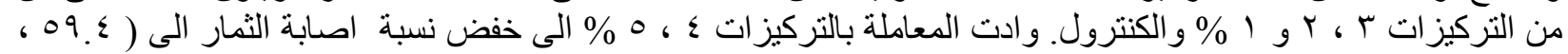

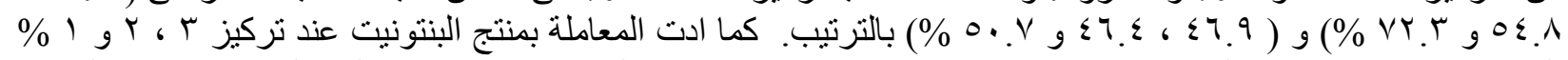

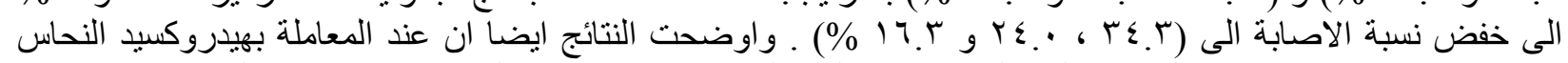

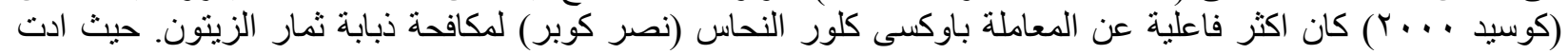

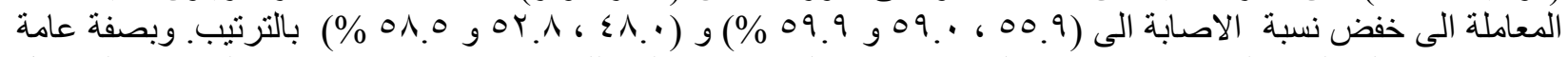

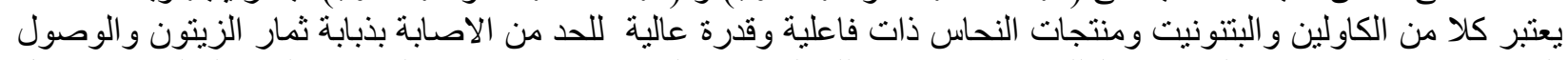

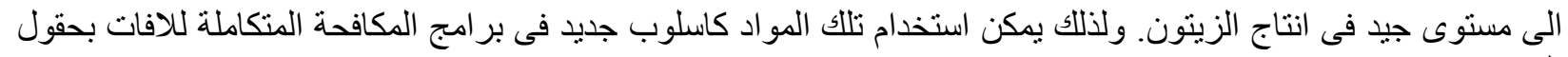

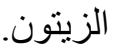
الكلمات الدالة :. ذبابة ثمار الزيتون ، الكاولين ، البنتونيت ، تكنولوجيا التغطية بالجزيئات ، منتجات النحاس 